\title{
The role of political competition in the link between electoral systems and corruption: an extension
}

Maria Rosaria Alfano, Seconda Università degli Studi di Napoli

Anna Laura Baraldi, Seconda Università degli Studi di Napoli

\begin{abstract}
This work provides an extension to an international context of the analysis made by Alfano, Baraldi and Cantabene (2013) on the role of political competition as a channel through which electoral systems affect corruption. Our result conflicts with that found by empirical literature on that topic that makes plurality rules the most virtuous in terms of corruption. Political scientists must be cautious in designing the degree of proportionality of electoral rules without take into account the variation in political competition that follows.
\end{abstract}

\section{Keywords}

Political competition; electoral systems; corruption.

\section{JEL Classification}

D72; C23; K42. 


\section{Introduction}

The choice of an electoral system is one of the most important institutional decisions for any democracy. A country's electoral system is the method used to calculate the number of elected positions in government that individuals and parties are awarded after elections. In other words, it is the way that votes are translated into seats in parliament or in other areas of government. There are many different types of electoral systems in use around the world, and even within individual countries, different electoral systems may be found in different regions and at different levels of government (e.g., for elections to school boards, city councils, state legislatures, governorships, etc.). The choice of a particular electoral system has a profound effect on the future political life of the country;the electoral system guarantees the representation of voters' desires and, once chosen, often remains fairly constant. Voting systems are generally divided into majoritarian/plurality rule and proportional representation (PR) with a number of variations and methods. In a democratic system, the mechanism of representation of political parties is also characterized by the degree of political competition among political parties and by the conflict between voters and candidates (the political corruption).

This work deals the effect of electoral systems on the level of corruption of a country. The wide literature studying the causes of corruption (Tanzi, 1998; Rose-Ackerman, 1999), considers the electoral system a most important political determinant of corruption. Indeed, in the public sector, corruption arises and persist when bureaucrats and politicians possess discretionary power which allows to extract economic rents. This happens when institutions (political, bureaucratic, juridical and economic) are weak (Aidt, 2011). Electoral rules characterize those institutions, as to the degree of political competitiveness among political parties. The theoretical literature investigating the relationship between the electoral system and corruption seems to conclude that the way in which electoral rules affect corruption depends on contrasting forces while the empirical literature suggests that countries with proportional systems have much more widespread corruption than countries with majoritarian systems (see subsection 2.1).

That literature, theoretical and empirical, seems to completely neglect the role played by political competition in the link between the electoral system and corruption. Political competition (defined as the competition among political parties to collect votes at elections, that is, as the competition for political power (Bardhan and Yang, 2004)) may be an important channel through which the electoral system affects corruption. Both the electoral system and political competition use the same mechanism to affect corruption: the accountability of incumbent politicians but, as for electoral rules, political competition may drive corruption in opposite directions. Moreover, we may believe that the electoral system has some effect on the degree of political competitiveness among political parties. Here we are interested in underlining that the literature, in particular the empirical literature, did not consider that political competition might affect corruption in combination with electoral systems. Alfano, Baraldi and Cantabene (2013) (hereafter ABC) were the first to attempt this unexplored issue. The deep analysis of the complex web wrapping electoral systems, political competition and corruption motivated the hypothesis formulated by $A B C$ that the electoral system may affect corruption directly and indirectly, via political competitions. The two effects may drive corruption in the same direction or in the opposite one; the total effect of the degree of proportionality of the electoral formula on corruption is the sum of the two effects. ABC use the suitable Italian scenario and the Gallagher disproportionality index as a measure of the degree of proportionality of an electoral system to test their hypothesis. They find that the way in which corruption is affected by the proportionality degree of an electoral system (that is, the total effect) depends on how the degree of political competition reacts to changes in the degree of proportionality of the electoral rule. The last issue is still unexplored. This powerful result underlines that it can be 
misleading to analyze the impact of electoral rules on corruption regardless of the role of political competition, and further investigations are encouraged.

We pick up the invitation of the authors. We extend the testing hypothesis of $A B C$ to an international context, on a cross-country panel data and we use different measures of corruption, available at the cross-country level, in order to check the robustness of results.

Our finding confirmed that of $A B C$. Firstly, the direct effect of the degree of proportionality on corruption is positive: an increase in proportionality of the electoral rule is beneficial for corruption. This result conflicts with that of previous empirical literature on a cross-country basis. The interpretation of this contrasting result is linked to the measure of the proportionality degree of the electoral system we used which allowed us properly to consider all electoral systems variants in an empirical setting. Secondly, as in $A B C$, we find that the indirect effects matter: political competitiveness is a channel through which the electoral system affects corruption and the direction of its effect depends on the degree of proportionality of the electoral system.

The paper is organized as follows. Section 2 summarizes the $A B C$ framework and shows the extension we made to their model. Section 3 describes the empirical model and variables we used. Section 4 explores the empirical strategy and shows the results. Section 5 presents the concluding remarks.

\section{The framework and the extension}

Before describing our work, we briefly summarize the general framework of the existing literature on the link between electoral systems and corruption which the $A B C$ analysis refers to.

\section{The $A B C$ framework}

The theoretical literature has explored the impact of electoral rules on corruption according to two dimensions: the district size (i.e. the number of seats in a district) and the electoral formula (i.e. how votes are translated into seats). Regarding the district size, PR promotes competition among politicians reducing the possibility of rent for incumbents (Myerson, 1993; Ferejohn, 1986); instead, looking at the electoral formula, the greater accountability of politicians induced by majoritarian representations provides a lower incentive for corruption than in PR (Persson and Tabellini, 1999a,b; 2000). Therefore, from the theoretical point of view, the effect of the electoral system on corruption goes in opposite directions. The empirical literature suggests that countries with proportional systems have much more widespread corruption than countries with majoritarian systems (Persson et al., 2003; Gagliarducci et al., 2011; Kunicova and Rose-Ackerman, 2005).

The study of effects of political competition on the economic variables is limited. Political competition may affect economic performance via the quality of politicians (Besley et al., 2010; Padovano and Ricciuti, 2009; Alfano and Baraldi, 2012). In the political economy literature, the concept of political competition seems close to that of accountability for incumbents (Persson et al., 1997): if political competition is intense, the incumbent politician is more accountable for his actions in office and has an incentive for good performances because, otherwise, he can be easily removed and replaced by the public, with challengers. Therefore, according to this concept, an intense political competition leads to less corruption (Mulligan and Tsui, 2006).Otherwise, when political competition is intense, the electoral base of each party tends to be smaller, the probability of re-election reduces and politicians have an incentive to adopt myopic behavior maximizing rents during their remaining time in office, and corruption increase (Stigler, 1972). Also for political competition, its effect on corruption is difficult to define. 
While it is widely documented that the party system is largely determined by the choice of the electoral system (Duverger, 1954; Cox, 1997; Lijphart, 1994; 1999; Sartori, 1976; Taagepera and Shugart, 1989), there is no evidence about the relationship between the latter and political competitiveness among parties. The number of political parties competing at the elections does not measure the degree of political competitiveness among them. As Sartori (1976) pointed out, for political competition, it is important, indeed, to consider the relative size of political parties (this will justify the choice of the Herfindahl index).

The electoral system and political competition use the same mechanism in order to affect corruption and it is not hard to assume that the electoral system has some effect on the degree of political competition.

This last consideration, within the framework of political determinants of corruption, motivated the $A B C$ analysis. $A B C$ advance in the empirical literature on the link between electoral systems and corruption in two ways. Firstly, they were the first that consider the role of political competition in the relationship between the electoral system and corruption. They argued that electoral systems, political competition and corruption are wrapped in a complex web and formulate the hypothesis that there is a direct and an indirect effect of electoral rules on corruption, the latter via political competition. Secondly, they distinguished electoral systems by using a continuous measure of their degree of proportionality (the Gallagher disproportionality index), differently from previous works which did that by using dummy variables (Persson et al., 2003). Indeed, the electoral rules a country decides to adopt defines the way in which votes obtained by political parties are translated into seats in Parliament; it defines the degree of proportionality of the electoral system. Therefore, in order to properly consider electoral systems in an empirical setting, a measure of its degree of proportionality is the correct way. A further advantage of such a measure of proportionality is the possibility to consider mixed electoral rule, beside the PR and majoritarian. Indeed, mixed electoral systems, combining PR and majoritarian elements, are more likely to be characterized by intermediate degrees of proportionality. ABC exploited the Gallagher disproportionality index (Gallagher, 1991) in order to treat Italian mixed systems, that is, to differentiate mixed rules that alternate according to their degree of proportionality during the time span they consider for the analysis. They computed the Gallagher index using the electoral outcomes of the Senate elections from 1979 to 2006 for the 20 Italian regions.

ABC tested their hypothesis on a sample of the 20 Italian regions since 1979 to 2005 arguing that it is a suitable scenario because of the particular characteristics of corruption and the electoral system. The hypothesis of the ABC analysis is that direct and indirect effects of electoral rules on corruption may drive corruption in the same direction or in the opposite direction depending on how the degree of political competition reacts to variations in the degree of proportionality of the electoral rule; therefore, the total effect of the electoral system on corruption is the sum of the two described effects.

$A B C$ measure the degree of political competitiveness among political partiesthrough the normalized Herfindahl index over the votes of each political party at elections from 1979 to 2006. The indirect effect of the electoral system on corruption has been caught by an interaction variable constructed by multiplying the two political indices just above described.

As a dependent variable, $A B C$ used the number of crimes against public administration and estimated a distributed lag model, where corruption is regressed on the past values of regressors. The reason of the choice of a distributed lag model relies on the kind of dependent variable they used. Indeed, corruption crimes perpetuated in a given year may be actually detected contemporaneously or with lags; crimes committed at different times can be detected contemporaneously; there is a lag between the beginning of the investigation and the conclusion of the penal action. Thus, the empirical model should allow for lags between the year the crime 
is committed and that of the sentence, that justifies the estimation of a distributed lag model, where corruption is regressed on the past values of regressors, with lags from 2 to 4 years.

$A B C$ found the following results:

- The direct effect of the degree of disproportionality of an electoral rule on corruption is positive: the more the degree of proportionality of the electoral system the less the level of corruption.

- The indirect effect shows that the way in which political competition affects corruption depends on the degree of proportionality of the electoral rule: there is a threshold of the degree of proportionality that allows us to separate an increase from a decrease of corruption due to an increase in the concentration of votes in the hands of political parties.

- The total effect depends on how political competition reacts to changes in the degree of proportionality. If the Gallagher index is below the threshold and if it is assumed that political competition moves in the same direction as the degree of proportionality of the electoral rule, the beneficial (negative) effect on corruption of an increase (decrease) in the degree of proportionality of the electoral system is reinforced by an increase (decrease) in political competition; otherwise, if the two indexed move in opposite direction, the two effects go in opposite direction and the total effect on corruption is indeterminate. When, instead, the value of the Gallagher index goes up to that threshold and an increase (decrease) in political competition follows an increase (decrease) in proportionality, the direct and indirect effects drive corruption in opposite directions; if the variations of the two political variables are reversed, the overall effect on corruption is the same. Table 1 below offers a graphical illustration of the $A B C$ results.

Table 1. Effects of the degree of proportionality of the electoral system on corruption

\begin{tabular}{c|ccccc}
\hline \multirow{2}{*}{$\begin{array}{c}\text { Effect on the } \\
\text { level of }\end{array}$} & \multicolumn{3}{c}{ Below the threshold } & \multicolumn{2}{c}{ Above the threshold } \\
\cline { 2 - 6 } corruption & Direct $(\Delta \mathrm{GDI})$ & $+(-)$ & $+(-)$ & $+(-)$ & $+(-)$ \\
& Indirect $(\Delta \mathrm{NHI})$ & $+(-)$ & $-(+)$ & $+(-)$ & $-(+)$ \\
& Total & $+(-)$ & $+/-$ & $+/-$ & $+(-)$ \\
\hline
\end{tabular}

The authors conclude, firstly, that this "within country" result contrasts with the previous cross-country one that, instead, stated that countries with PR have much more widespread corruption thancountries with majoritarian representations (Persson et al., 2003); secondly, that, assuming a variation in the degree of proportionality of the electoral system only, is not sufficient to establish what is the consequent trend of corruption; how political competition reacts to some changes in the degree of proportionality should allow us to draw conclusions. The relationship between the electoral system and political competition still remains unexplored.

\section{The extension}

The hypothesis that $A B C$ test and the results they found are very interesting within the political determinants of corruption framework. But, as they suggest, further investigations in that topic are needed. The present work tries to fill some weaknesses of the $A B C$ analysis; in detail, we are referring to:

1) the "within-country" analysis. Italy certainly provides a suitable scenario, but results (as the authors stressed) could be unresponsive to other realities;

2) the Gallagher index, although it is on the Italian regional basis, was computed under the same electoral rule over time. That is, changes in the Italian electoral 
system during the period under exam concerned all the regions at the same time. This is the reason why the Gallagher index showed little variability across regions (indeed, it ranges from 0.02 to 0.52 );

3 ) the cross-sectional dimension of the Italian panel data is short $(\mathrm{N}=20$ Italian regions); this may create some problem in estimations using the system GMM technique which, instead, is designed for panel with short $\mathrm{T}$ and long $\mathrm{N}$.

Thus, we test the same hypothesis as $A B C$ to a cross-country scenario. We conduct the empirical analysis on a panel of 85 countries over 28 years (from 1984 to 2010). This extension to ABC's work allows us to compare our results with those previously found by the literature. It seems very interesting to the light of the more suitable measure we used to distinguish electoral systems and their degrees of proportionality that were never done before. Moreover, the panel dimensions are perfect to exploit the system GMM estimation technique.

\section{The empirical model and variables}

The estimated equation of country $i$ at time $t$ is

$$
\begin{aligned}
& \operatorname{Corr}_{i, t}=\sum \operatorname{Corr}_{i, t-j}+\beta_{1} G D I+\beta_{2} H I+\beta_{3}(G D I * H I)+\sum \delta \text { regressors }_{i, t}+ \\
& +\alpha_{i}+\mu_{t}+\varepsilon_{i, t}
\end{aligned}
$$

Where $\alpha_{i}$ is a country specific effect, $\mu_{\mathrm{t}}$ is a time-specific effect. The dependent variable is the Corruption index (thereafter Corr) provided by the International Country Risk Guide - ICRG. (Even though the ICRG database includes a collection of records for about 150 countries, our analysis is cut off from some countries which showed few observations. Therefore we reduced the dataset to 85 countries. Table A1, Appendix, provides a full description of the variable.) It is a measure of "perceived" corruption and is one of the three most popular indices based on corruption perception. The other two are the Corruption Perception Index (by Transparency International) and the Control of Corruption index (by the World Bank). It summarizes the valuation of corruption within the political system; in particular, it deals with the warning for foreign investments. The Corruption index ranges in an interval [0 to 6] where 0 represents the highest risk of corruption and 6 is the lowest risk; it provides the longer time series of corruption data, from 1984 to 2010. Tables A2 and A3, Appendix, show respectively the descriptive statistics of Corr and partial correlation.

Figure 1 below shows an overview of the Corruption index distribution for different countries. For each country in the figure we calculated the mean over years (19842010). To the left with a high index value (meaning low corruption risk) we find the Scandinavian countries and the three countries of Oceania (Australia, New Zealand and Papua New Guinea). European countries in the dataset show low/medium levels of corruption while countries in Asia, Africa and South America have the highest value.

Figure 1. Mean of Corruption index over the years

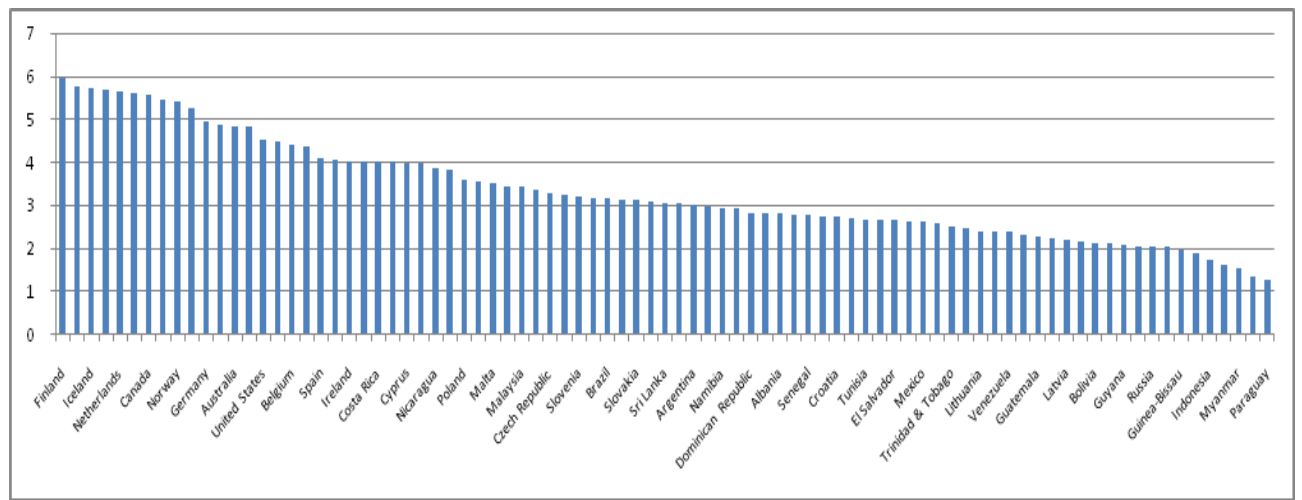


The dynamic panel data model (as equation (1)) can be identified only for stationary time series cross-sectional data; therefore, a panel test for unit roots on the dependent variable Corr is needed. We perform the Fisher-type test developed by Maddala and $\mathrm{Wu}$ (1999). A Fisher-type test combines the p-values from $\mathrm{N}$ independent unit root tests. It is based on the p-values of individual unit root test; the null hypothesis is that all series are non-stationary against the alternative that at least one series in the panel is stationary. We chose this test because it does not require a balanced panel. At 1 percent we reject the null hypothesis of non-stationary series, thus our dependent variable does not show unit root. We perform the Fisher-type test including drift and 1, 2 and 3 lags in the individual ADF regressions. We always reject the null. The test is not shown.

Two lags of the dependent variable are introduced in the estimated equation because of the dynamic of corruption (Aidt, 2003). Estimations of equation (1) without lags of Corr showed autocorrelation of residuals. In order to solve this problem, we introduced two lags of the dependent variable in the right-side of equation (1).

The two regressors of our interest are political indices.

The first one, as mentioned above, is the Gallagher disproportionality index. As in $A B C$, we use it as a measure of the degree of proportionality of the electoral system. As for the within-country analysis, this is a novelty also in the cross-country empirical literature on the effects of electoral systems on corruption. The Gallagher index (or least squares index) is a representation index of political parties within a Parliament; it may be considered as a very good proxy for the degree of proportionality of an electoral system because the electoral system that guarantees a greater representation of political parties is a more proportional one while the less representative one is less proportional. Moreover, empirical studies have shown that a majoritarian system produces a higher level of disproportionality than a proportional representation system (Lijphart, 1994; Anckar, 2001), whereas a mixedelectoral system produces an intermediate level (Powell and Vanberg, 2000; Anckar, 2001). The Gallagher index (thereafter $G D I$ ) is constructed as

$$
G D I=\sqrt{\frac{1}{2} \sum_{i}\left(v_{i}-s_{i}\right)^{2}}
$$

where $v_{i}$ and $s_{i}$ are respectively the share of votes and of seats of a single political party $(\mathrm{i}=1, \ldots ., \mathrm{n}$ political parties) at elections in each country in the time span under consideration. The index may range from 0 to 100 with 100 indicating perfect proportionality between seats and votes and 0 meaning that the only seat at stake goes to the winner (in which case the index equals the percentage of votes obtained by the defeated candidate). Clearly the bounds of the GDI (0 and 100) are only theoretical values. Among the investigated countries, the GDI ranges from 0.26 to about 33 (see table A2, Appendix, for the descriptive statistics of the GDI). The dataset comprises countries that experienced majoritarian, proportional and mixed systems. The upper bound of the GDI (33.25) is very far from the theoretical value of 100 of perfect disproportionality. This means that also countries under plurality rules have a relatively strong proportionality. Therefore, all the three systems have a certain degree of proportionality; moving from PR to majoritarian systems, such degree of proportionality decreases.

The other political index measures the political competitiveness among political parties at elections. It is the Herfindahl index $(\mathrm{HI})$ calculated as:

$$
H I=\sum_{i=1}^{n} v_{i}^{2}
$$


where $v_{i}$ is the vote share of a single political party at elections in each country from 1984 to 2010 and $n$ is the number of political parties at each election. It ranges from 0 (theoretically perfect competition with $n$ equally sized parties) to 1 (monopoly) and it is open on the lower bound. The Herfindahl index is usually used to measure the size of firms in relation to an industry; therefore, it is an indicator of the amount of competition among them. Following Stigler (1972), which interprets competition in the market for votes as competition in the goods' market (the more competitive the parties, the more responsive the political system will be to the desires of the majority), an index of goods' market power seems the correct way to measure the market for votes' power. ABC employed the normalized Herfindahl index because of its desirable properties for that kind of analysis. We are forced to use the standard Herfindahl index because we are unable to collect the number of political parties at elections in each country, required to construct the normalized Herfindahl index. Table A2, Appendix, summarizes the descriptive statistics of this index.

The direct effect of the degree of proportionality on corruption is caught by the coefficient $\beta 1$ in eqaution (1). The indirect effect is caught by the coefficient $\beta 3$ of the interaction term $G D I * H I$.

De Haan and Seldadyo (2005) in their survey on the causes of corruption, detect tens of such determinants. Among them, we chose, as control variables, those we believed the more suitable for the analysis we will perform. Therefore, control variables are:

- Per capita GDP, in natural log (Ingdp); it controls for structural differences in economic development (De Haan and Seldadyo, 2005). We expect its positive correlation with perceived corruption (Ades and Di Tella, 1999; La Porta et al., 1999; Treisman 2000). Hall and Jones (1999) and Kaufmann et al. (1999) question the causal relationship between corruption and income: the per capita GDP is high because of low corruption. For this reason we treat Ingdp as endogenous.

- Population (pop); it controls for country size. Empirical literature found contrasting evidence (Knack and Azfar, 2003; Tavares, 2003).

- Government stability (gov_stab); it controls for quality of government. The higher the quality of government, the lower the probability of corruption (de Haan and Seldadyo, 2005).

- Democratic accountability (dem); it controls for the level of democracy of a country. There is a general consensus that democracy reduces corruption (de Haan and Seldadyo, 2005).

- Freedom of press (press); it controls for democratic governance. Informed voters are better able to hold elected officials accountable for their policy decisions; the greatest part of people get their information via the media (Snyder and Stromberg, 2008). This variable is found to be negatively correlated with corruption (Brunetti and Weder, 2003).

- Law and Order (law_order); it controls for the rule of law as a measure of the confidence that agents have in the rules of society, the effectiveness of judiciary and the enforceability of contracts (de Haan and Seldadyo, 2005). A stronger rule of law reduces the likelihood of corruption to take place. Also in this regard, an issue of causality may emerge: agents may have trust in the rule of law because corruption is low. In order to take this problem into account, in some estimations we treat law_order as endogenous.

- Woman (wom); it is the proportion of seats held by women in national parliaments (percentage); it controls for the gender dimension of corruption meaning that conventional wisdom states that women in public life can be an 
effective anticorruption strategy because women are less corruptible than men (Dollar et al., 1999; Goetz, 2004; Sung, 2003).

- General government consumption expenditure $(G)$; it controls for government size. There is no consensus among authors on the theoretical relationship between government size and corruption (Abdiweli and Hodan, 2003; Bonaglia et al., 2001; Fisman and Gatti, 2002). We normalize general government consumption expenditure in percentage of GDP and per capita.

- Net enrollment primary rate, in natural log (Inschool); it controls for the human capital development. Empirical literature found contrasting evidence (Ali and Isse, 2003; Frechette, 2001). Tables A.1, A.2 and A.3, Appendix, show respectively the detailed description of all the variables, the statisticsand the correlation matrix.

We follow standard practice of counting a country as democratic according to its rate of Polity IV political freedom score; we define as a democracy a country which scores a Polity IV index greater than +3 in the year of the election (Gleditsch and Hegre, 1997). See table A.1 for a detailed description of this index and table A.2 for its descriptive statistics.

In order to generalize the estimation results, we will provide robustness checks by using other measures of corruption available at cross-country level.

\section{Empirics}

\section{Empirical strategy}

Equation (1) is a dynamic panel data model which has been estimated using Arellano-Bover (1995)/Blundell-Bond (1998) system GMM estimators; ${ }^{1}$ estimation results are shown in Table 2. The empirical analysis has been conducted on a panel of 85 countries over 28 years (from 1984 to 2010). In order to control for heteroskedasticity, every estimated equation has cluster-robust standard errors. The second-last raw of Table 2 (see sub-section 4.1) shows the Chi-squared (and the pvalue in parentheses) of the Hansen test whose null hypothesis is that the overidentification restrictions are valid; we do not reject the null and the model is correctly specified. (We also compute, but we do not show, the difference-in-Hansen test in order to test the joint validity of the full instrument set; we do not reject the null.) The last raw of Table 2 displays the $p$-value of the Arellano-Bond test for second-order autocorrelation in the first differenced residuals; the null hypothesis is the absence of autocorrelation of residuals that we always accept.In order to control for common shocks in a given year, calendar year dummies are included. (In Table 2 of estimation results we do not display such dummies.) Every specification in Table 2 is estimated by the two-step options with the Windmeijer (2005) correction. Windmeijer (2005) finds that the two-step efficient GMM performs somewhat better than one-step in estimating coefficients, with lower bias and standard errors, and that the two-step estimation with corrected errors is superior to robust one-step.

We start estimating equation (1) including the two typical controls in cross-country analysis, the (log of) per capita GDP and the population size; in order to test the robustness of results, in the following specifications we add, step by step, all the control variables described above. All the regressors in equation (1) are introduced contemporaneously: given that our dependent variable is an index of perceived corruption, we have no reason to believe that this perception by citizens is affected

\footnotetext{
${ }^{1}$ We used the Stata command xtabond2 provided by David Roodman (2009)
} 
by past values of the variables. This is the reason why we do not introduce lag structure in the estimated model. An important issue here is to deal with the possibility of endogeneity of the Gallagher index. First of all, the theoretical literature analyzing the link between electoral rules and corruption considers the first as a determinant of corruption and not the reverse. Second, it seems unlike to think that the perception of corruption (as a menace for foreign investments) may affect the way in which electoral system is designed by politicians; third, it seems also unlike to believe that a more or less corrupt system may affect the way in which votes are translated in seats, as the electoral system does. However, an endogeneity problem may arise when dealing with political institutions, that is, there may be some omitted factors that influence electoral systems and simultaneously influence corruption.In order to verify the exogeneity of $G D I$ we perform the $C$ test on the $G D I$ variable. Under the null, the Hansen statistic tests the validity of a subset of orthogonality conditions. To perform the $C$ test we have to estimate two models, one where $\mathrm{Gl}$ is exogenous and another where the $\mathrm{Gl}$ is endogenous. The estimation of the first model gives us a Hansen statistic (called $\mathrm{H} 1$ ) and the estimation of the second model gives us another Hansen statistic (called $\mathrm{H} 2$ ). We need to use the same set of exogenous instruments for both estimations that is we have to assume that all the other orthogonality conditions hold, i.e. all the other included and excluded instruments remain exogenous. $\mathrm{H} 1$ and $\mathrm{H} 2$ are both distributed as a Chi-squared with the dof of $\mathrm{H} 2$ smaller than the dof of $\mathrm{H} 1$. The $\mathrm{C}$ test on $\mathrm{Gl}$ is simply a test of $\mathrm{H} 1$ $\mathrm{H} 2$. The test statistic H1-H2 is distributed as Chi-squared with dof equal to the number of regressors being tested for endogeneity (in our case 1, GDI). If it is endogenous, then $\mathrm{H} 1-\mathrm{H} 2$ will be high because $\mathrm{H} 1$ is high while $\mathrm{H} 2$ is not. In order to deal with the general endogeneity issue, system GMM treats the model as a system of equations-one for each time period - where the predetermined and endogenous variables in first differences are instrumented with suitable lags of their own levels (see Table A4, Appendix). Columns (a) and (a') display the estimates of equation (1) where $G D I$ is treated respectively as exogenous and endogenous (only with Ingdp and pop as control variables). This allows us to calculate the statistic ( $\mathrm{H} 1-\mathrm{H} 2)$. It is distributed as a Chi-squared with dof $=1$ and it is equal to 0.03 . Looking at the critical value of the Chi-squared distribution with 1dof, the test says that at 1 percent we do not reject the null: $G D I$ is exogenous. Moreover, the coefficients of $G D I, H I$ and $G D / * H I$ are significant when $G D I$ is endogenous.

As mentioned above, the per capita GDP is treated as endogenous and it is instrumented with its own lags. We treat the low and order variable as exogenous and endogenous; where endogenous, it is instrumented with its own lags. 


\section{Results}

Table 2. Estimation results. Dependent variable: Corruption Index

\begin{tabular}{|c|c|c|c|c|c|c|c|c|c|c|}
\hline & (a) & (b) & (c) & $\left(c^{\prime}\right)$ & (d) & $\left(d^{\prime}\right)$ & (e) & $(f)$ & $\left(f^{\prime}\right)$ & (g) \\
\hline corr (-1) & $\begin{array}{c}1.08^{\star \star \star} \\
(20.8)\end{array}$ & $\begin{array}{c}1.03^{\star \star \star} \\
(16)\end{array}$ & $\begin{array}{l}1.01^{\star \star \star} \\
(14.4)\end{array}$ & $\begin{array}{c}1.08^{\star \star \star} \\
(12.5)\end{array}$ & $\begin{array}{c}1.04^{\star \star \star} \\
(15.7)\end{array}$ & $\begin{array}{c}1.04^{\star \star \star} \\
(14.6)\end{array}$ & $\begin{array}{c}0.99 \star \star \star \\
(12)\end{array}$ & $\begin{array}{c}1.05^{\star \star \star} \\
(15)\end{array}$ & $\begin{array}{c}1.04^{\star \star \star} \\
(15)\end{array}$ & $\begin{array}{c}0.98^{\star \star \star} \\
(8.03)\end{array}$ \\
\hline corr (-2) & $\begin{array}{c}0.23^{\star \star \star} \\
(-5.7)\end{array}$ & $\begin{array}{c}- \\
0.21^{\star \star \star} \\
(-5.3)\end{array}$ & $\begin{array}{c}0.21^{\star \star \star} \\
(-4)\end{array}$ & $\begin{array}{c}0.23^{\star \star \star} \\
(-3.3)\end{array}$ & $\begin{array}{c}0.21^{\star * \star} \\
(-4.4)\end{array}$ & $\begin{array}{c}0.22^{\star \star \star} \\
(-5)\end{array}$ & $\begin{array}{c}- \\
0.21^{\star \star \star} \\
(-4.2)\end{array}$ & $\begin{array}{c}- \\
0.21^{\star \star \star} \\
(-4.3)\end{array}$ & $\begin{array}{c}- \\
0.21^{\star \star \star} \\
(-4.5)\end{array}$ & $\begin{array}{c}-0.17^{\star *} \\
(-2.2)\end{array}$ \\
\hline GDI & $\begin{array}{l}-0.01^{\star *} \\
(-2.23)\end{array}$ & $\begin{array}{l}-0.01^{\star *} \\
(-2.28)\end{array}$ & $\begin{array}{c}-0.01^{*} \\
(-3)\end{array}$ & $\begin{array}{c}-0.01^{*} \\
(-1.77)\end{array}$ & $\begin{array}{c}- \\
0.01^{\star \star \star} \\
-3.18)\end{array}$ & $\begin{array}{c}- \\
0.01^{\star \star \star} \\
(-2.7)\end{array}$ & $\begin{array}{c}-0.01^{* *} \\
(-2.5)\end{array}$ & $\begin{array}{c}- \\
0.01^{\star \star \star} \\
(-2.88)\end{array}$ & $\begin{array}{c}- \\
0.01^{\star \star *} \\
(-3.04)\end{array}$ & $\begin{array}{c}-0.01^{* *} \\
(-2.1)\end{array}$ \\
\hline $\mathrm{HI}$ & $\begin{array}{l}-0.48^{\star \star} \\
(-1.92)\end{array}$ & $\begin{array}{l}-0.6^{\star \star} \\
(-2.03)\end{array}$ & $\begin{array}{c}-0.8^{\star} \\
(-2.6)\end{array}$ & $\begin{array}{l}-0.36^{*} \\
(-1.72)\end{array}$ & $\begin{array}{l}-0.6^{\star \star} \\
(-2.10)\end{array}$ & $\begin{array}{l}-0.67^{\star} \\
(-1.86)\end{array}$ & $\begin{array}{l}-0.41^{*} \\
(-1.62)\end{array}$ & $\begin{array}{l}-0.54^{*} \\
(-1.8)\end{array}$ & $\begin{array}{l}-0.59 * \star \\
(-2.01)\end{array}$ & $\begin{array}{c}-0.43^{*} \\
(-1.8)\end{array}$ \\
\hline GDI *HI & $\begin{array}{c}0.02^{* * *} \\
(2.6)\end{array}$ & $\begin{array}{l}0.02^{* *} \\
(2.49)\end{array}$ & $\begin{array}{l}0.03^{*} \\
(3.2)\end{array}$ & $\begin{array}{l}0.02^{* *} \\
(2.23)\end{array}$ & $\begin{array}{c}0.03^{\star \star \star \star ~} \\
(2.8)\end{array}$ & $\begin{array}{l}0.03^{\star * \star} \\
(3.02)\end{array}$ & $\begin{array}{l}0.02^{* *} \\
(1.92)\end{array}$ & $\begin{array}{c}0.03^{\star \star} \\
(2.5)\end{array}$ & $\begin{array}{l}0.03^{* * *} \\
(2.63)\end{array}$ & $\begin{array}{l}0.02^{*} \\
(1.8)\end{array}$ \\
\hline Ingdp & $\begin{array}{c}0.02 \\
(0.7) \\
-5.77 \mathrm{e}-\end{array}$ & $\begin{array}{c}0.02 \\
(0.5) \\
-8.90 \mathrm{e}-\end{array}$ & $\begin{array}{c}-0.05 \\
(-0.7) \\
-2.05 \mathrm{e}-\end{array}$ & $\begin{array}{c}0.03 \\
(1) \\
5.63 \mathrm{e}-\end{array}$ & $\begin{array}{c}-0.09 \\
(-1.1) \\
-1.08 \mathrm{e}-\end{array}$ & $\begin{array}{c}-0.06 \\
(0.9) \\
-1.45 \mathrm{e}-\end{array}$ & $\begin{array}{c}-0.02 \\
(-0.26) \\
3.30 \mathrm{e}-\end{array}$ & $\begin{array}{c}-0.08 \\
(-1.09) \\
-1.14 \mathrm{e}-\end{array}$ & $\begin{array}{c}-0.09 \\
(-1.1) \\
-7.88 \mathrm{e}-\end{array}$ & $\begin{array}{c}0.03 \\
(0.4) \\
1.84 \mathrm{e}-\end{array}$ \\
\hline pop & $\begin{array}{c}11 \\
(-0.5)\end{array}$ & $\begin{array}{c}11 \\
(-0.7)\end{array}$ & & $\begin{array}{c}11 \\
(0.8)\end{array}$ & $\begin{array}{c}10 \\
(-0.7)\end{array}$ & $\begin{array}{c}10 \\
(-0.8)\end{array}$ & $\begin{array}{c}11 \\
(0.27)\end{array}$ & $\begin{array}{c}-1.14 \mathrm{C}^{-} \\
10 \\
(-0.7)\end{array}$ & $\begin{array}{c}1.000^{-} \\
(-0.4)\end{array}$ & $\begin{array}{c}1.04 E^{-} \\
11 \\
(0.1)\end{array}$ \\
\hline gov_stab & & $\begin{array}{c}0.05^{\star \star *} \\
(3.1)\end{array}$ & $\begin{array}{l}0.05^{\star} \\
(2.95)\end{array}$ & $\begin{array}{l}0.03^{\star \star} \\
(1.96)\end{array}$ & $\begin{array}{c}0.03^{\star *} \\
(2.4)\end{array}$ & $\begin{array}{c}0.04 \\
(1.54)\end{array}$ & $\begin{array}{c}0.03^{\star * *} \\
(2.7)\end{array}$ & $\begin{array}{l}0.03^{* *} \\
(2.17)\end{array}$ & $\begin{array}{c}0.03^{* *} \\
(2.2)\end{array}$ & $\begin{array}{c}0.03 \\
(1.48)\end{array}$ \\
\hline $\begin{array}{l}\text { dem } \\
\text { press }\end{array}$ & & & $\begin{array}{l}0.05^{\star \star} \\
(1.96)\end{array}$ & $\begin{array}{c}0.003 \\
(0.2) \\
-0.004 \\
(-1.1)\end{array}$ & $\begin{array}{l}0.003 \\
(2.39)\end{array}$ & $\begin{array}{l}0.02 \\
(0.5)\end{array}$ & & $\begin{array}{l}0.004 \\
(0.35)\end{array}$ & $\begin{array}{c}0.006 \\
(0.5)\end{array}$ & $\begin{array}{l}-0.01^{*} \\
(-0.7)\end{array}$ \\
\hline law_order & & & & & $\begin{array}{c}0.15^{\star \star *} \\
(2.73)\end{array}$ & $\begin{array}{l}0.06 \\
(0.5)\end{array}$ & $\begin{array}{c}0.12^{\star * *} \\
(2.11)\end{array}$ & $\begin{array}{c}0.13^{\star \star *} \\
(2.6)\end{array}$ & $\begin{array}{c}0.14^{\star \star *} \\
(2.7)\end{array}$ & $\begin{array}{l}0.10 \\
(1.3)\end{array}$ \\
\hline women & & & & & & & $\begin{array}{c}0.006^{\star *} \\
(2.14)\end{array}$ & & & \\
\hline G/GDP & & & & & & & & $\begin{array}{c}0.003 \\
(0.8)\end{array}$ & & \\
\hline G/POP & & & & & & & & & $\begin{array}{l}0.08^{*} \\
(0.8)\end{array}$ & \\
\hline Inschool & & & & & & & & & & $\begin{array}{c}0.6 \\
(0.8)\end{array}$ \\
\hline $\begin{array}{l}\text { N. obs. } \\
\text { (n. } \\
\text { groups) }\end{array}$ & $\begin{array}{c}1303 \\
(70)\end{array}$ & $\begin{array}{c}1298 \\
(70)\end{array}$ & $\begin{array}{c}1191 \\
(69)\end{array}$ & $\begin{array}{l}1151 \\
(70)\end{array}$ & $\begin{array}{c}1191 \\
(69)\end{array}$ & $\begin{array}{c}1191 \\
(69)\end{array}$ & $\begin{array}{c}1155 \\
(69)\end{array}$ & $\begin{array}{c}1182 \\
(69)\end{array}$ & $\begin{array}{c}1182 \\
(69)\end{array}$ & $\begin{array}{l}697 \\
(65)\end{array}$ \\
\hline $\begin{array}{l}\mathrm{N} . \\
\text { instrum. }\end{array}$ & 36 & 37 & 47 & 41 & 47 & 48 & 47 & 48 & 48 & 49 \\
\hline $\begin{array}{l}\text { Chi2 (p- } \\
\text { value) } \\
\text { Hansen } \\
\text { test }\end{array}$ & $\begin{array}{c}1.1 \\
(0.89)\end{array}$ & $\begin{array}{c}1.9 \\
(0.7)\end{array}$ & $\begin{array}{l}12.4 \\
(0.5)\end{array}$ & $\begin{array}{c}6.6 \\
(0.35)\end{array}$ & $\begin{array}{c}10.4 \\
(0.58)\end{array}$ & $\begin{array}{c}11.9 \\
(0.53)\end{array}$ & $\begin{array}{l}9.36 \\
(0.7)\end{array}$ & $\begin{array}{c}11.6 \\
(0.47)\end{array}$ & $\begin{array}{l}10.2 \\
(0.6)\end{array}$ & $\begin{array}{c}17.3 \\
(0.18)\end{array}$ \\
\hline $\begin{array}{l}\text { p-value } \\
\text { 2nd } \\
\text { order } \\
\text { autocor }\end{array}$ & 0.17 & 0.13 & 0.12 & 0.12 & 0.18 & 0.14 & 0.25 & 0.17 & 0.2 & 0.9 \\
\hline $\begin{array}{l}\text { Jotes. All } \\
\text { 010. The } \\
\text { obust sta } \\
\text { aw_order }\end{array}$ & (10\% & III & 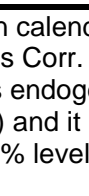 & $d * x$ & nies & 0 & tim & wi & $\begin{array}{l}\text { ses; } \\
\text { wn I }\end{array}$ & $\begin{array}{l}\text { 84- } \\
\text { ter- }\end{array}$ \\
\hline
\end{tabular}

Specification (a) contains only the per capita GDP (in natural log) and population; the specifications which follow contain all the control variables we described above. The signs and significance of the political indices of interest do not change in every specification. At the cross-country level, our findings exactly confirm those in ABC. The coefficient of the $G D I$ is negative everywhere; recalling that it is a disproportionality index, the more the degree of proportionality of the electoral system, the less the level of corruption (remember also that the higher the value of the Corruption index, the lower the level of corruption). This result states that the direct effect of the proportionality of the electoral system on corruption is positive also at the cross-country level and contradicts the previous empirical findings of Persson et al. (2003). This may be due to the fact that we distinguish electoral 
systems according to their degree of proportionality instead of dummy variables; in our opinion, as stated above, the measure of proportionality is the correct way to identify electoral rules in an empirical setting. The magnitude of $\beta_{1}$ is 0.01 meaning that if the proportionality increases, for example, by 0.1 , the level of corruption decreases by 0.001 . The $\mathrm{HI}$ shows a negative and significant coefficient equal, on average, to 0.55: a decrease in this index means an increase in political competition which is beneficial for corruption. Finally, the novelty of the present work (as that of $A B C$ ) is the interpretation of the interaction term $G D I^{*} H I$, capturing the indirect effect of the degree of proportionality of the electoral system on corruption. Looking at the specification (a), we can write

$$
\frac{\partial c o r r}{\partial H I}=-0.48+0.02 * G D I
$$

that is, the effect of political concentration on corruption depends positively on the degree of disproportionality of the electoral system. In equation (2), there is a threshold value of the $G D I(G D I=24)$ such that if $G D I>24, \frac{\partial c o r r}{\partial H I}>0$, if $G D I<24$, $\frac{\partial c o r r}{\partial H I}<0$. (The threshold value of $G D I$ is the value such that $\frac{\partial c o r r}{\partial H I}=0$ in equation (2). This is equal to 24.)

Therefore, an increase in political competition may have a positive or negative impact on corruption depending on whether the variable $G D I$ is above or below that threshold value. The threshold values slightly change according to the estimated coefficients of specifications in Table 2. We can now deal with the total effect of the degree of proportionality of the electoral system on corruption. It depends on how political competition reacts to changes in the degree of proportionality of the electoral system. Where electoral systems are characterized by high degrees of proportionality, an increase (decrease) in their degrees of proportionality followed by an increase (decrease) in political competition, is beneficial (is not beneficial) for corruption because the direct and the indirect effects go in the same direction. Otherwise, under less proportional electoral systems (GDI above 24), an increase (decrease) in political competition which follows an increase (decrease) in proportionality, leads to the direct and the indirect effects in opposite directions. In this situation, in order to reduce corruption, an increase in the degree of proportionality should be followed by a reduction in political competitiveness. Therefore, if the change in political competition has the same sign as the change in the degree of proportionality of the electoral formula, the indirect effect strengthens the direct effect under more proportional rules and it mitigates the direct effect on corruption under less proportional regimes.

In terms of the data, only few countries in few years of elections experienced a degree of proportionality greater than 24 . (Those countries are Albania, Bahamas, France, Jamaica, Mongolia, Papua New Guinea, Philippines, Sri Lanka, Trinidad \& Tobago and Turkey.)

This means that, according to our estimation, the relevant case to be considered is $\frac{\partial c o r r}{\partial H I}<0$.

Now look at the other variables. Past values of Corr are always highly significant and the long-run effect is positive, as expected. The introduction of all the control variables does not change the results. The Ingdp and pop are never significant. The government stability (gov_stab) is positive and significant, as expected, almost everywhere with magnitude, on average, of 0.03 : an increase of 0.1 in government stability index leads to an increase in the Corruption index (that is, a decrease in corruption) of 0.003 . In columns (c) and (c') we introduce demand press: they are 
both variables related to the democratization of countries. [D]emis positive, as expected, and significant in (c); when we introduce press in (c'), dem loses significance and press is not significant. We drop this latter from the following estimations. [L]ow_order is positive everywhere and significant only where it is exogenous (in (d') it is treated as endogenous): a stronger rule of law is confirmed to deter corrupt behaviour. A positive sign is confirmed also for the presence of women in the country's parliament. As a proxy for the government size, we control for both public consumption spending/GDP and public consumption spending/population. Only the second one is significant with positive sign. Finally, the rate of schooling seems to have no relevance in the explanation of corruption.

\section{Robustness analysis}

We perform a further robustness check of the analysis, concerning the dependent variable. We test the same model with the two other most widely used indicators of corruption worldwide: the Corruption Perceived Index (hereafter $C P I$ ) and the Control of Corruption Index (hereafter $C_{-} C$ ). The $C_{\text {PI }}$ measures the perceived levels of public sector corruption (CPI, 2012). Based on expert opinion, countries are scored from 0 (highly corrupt) to 10 (very clean). $C_{-}$C Index reflects perceptions of the extent to which public power is exercized for private gain capturing all the forms of corruption by which elites and private interests take advantage from public sector. It ranges from approximately -2.5 (high corruption) to 2.5 (low corruption). (See Tables A1 and A2 for the description and statistics of those variables.) The estimation results are in Table 3 where we introduce, as controls, only Ingdp and pop. ${ }^{2}$

Table 3. Estimations. Dependent variables: $C P I$ and $C \_C$

\begin{tabular}{|c|c|c|}
\hline & $\begin{array}{c}\text { (h) } \\
\text { Dep. Var.: CPI }\end{array}$ & $\begin{array}{c}\text { (i) } \\
\text { Dep. Var.: C_C }\end{array}$ \\
\hline CPI $(-1)$ & $\begin{array}{l}0.05 \\
(0.9)\end{array}$ & \\
\hline CPI (-2) & $\begin{array}{l}0.46^{\star *} \\
(2.1)\end{array}$ & \\
\hline C_C $(-1)$ & & $\begin{array}{l}-0.08 \\
(0.5)\end{array}$ \\
\hline GDI & $\begin{array}{l}-0.08^{\star} \\
(-1.9)\end{array}$ & $\begin{array}{c}-0.05^{\star *} \\
(-2)\end{array}$ \\
\hline $\mathrm{HI}$ & $\begin{array}{l}-1.81^{*} \\
(-1.9)\end{array}$ & $\begin{array}{l}-1.78^{*} \\
(-1.82)\end{array}$ \\
\hline GDI *HI & $\begin{array}{l}0.25^{\star \star} \\
(2)\end{array}$ & $\begin{array}{l}0.11^{*} \\
(1.65)\end{array}$ \\
\hline Ingdp & $\begin{array}{c}0.4 \\
(1.2)\end{array}$ & $\begin{array}{l}0.33^{*} \\
(1.66)\end{array}$ \\
\hline pop & $\begin{array}{c}-2.15 e-10 \\
(-0.5)\end{array}$ & $\begin{array}{c}-6.63 e-10^{*} \\
(-1.21)\end{array}$ \\
\hline N. obs. (n. groups) & $734(67)$ & $540(69)$ \\
\hline N. instrum. & 39 & 35 \\
\hline Chi2 (p-value) & 21.4 & 25.3 \\
\hline Hansen test & $(0.2)$ & $(0.2)$ \\
\hline $\begin{array}{l}\text { p-value } 2 \text { nd order } \\
\text { autocorrelation }\end{array}$ & 0.2 & 0.7 \\
\hline \multicolumn{3}{|c|}{$\begin{array}{l}\text { Notes. CPI is the Corruption Perception Index; C_C is the Control of Corruption Index. All specifications } \\
\text { contain calendar year dummies (results not reported); in (h) the time span is } 1995-2011 ; \text { in (i) the time } \\
\text { span is 2002-2011. Standardized normal z-test values are in parentheses; cluster-robust standard } \\
\text { errors. Ingdp is endogenous everywhere. Significant coefficients are indicated by * (10\% level), }{ }^{* *}(5 \% \\
\text { level) and }{ }^{* \star *}(1 \% \text { level). Two-step estimations with Windmeijer (2005) correction. }\end{array}$} \\
\hline
\end{tabular}

As we can notice, both direct and indirect effects of the degree of proportionality of the electoral system on corruption remain robust to different measures of corruption. The number of observations drastically decreases because the time span is 1995-

\footnotetext{
${ }^{2}$ In the estimation with $C_{-}$C as dependent variable, in column (i) Table 3, we introduce only one lag of the dependent variable because it is enough to remove the autocorrelation of residuals.
} 
2011 for the CPI and 2002-2011 for the C_C. The estimated coefficients for GDI, HI and the interaction $G D I^{*} H I$ show that the threshold values of the $G D I$ fall into the allowable range: it is equal to 7.24 when the dependent variable is the $C P I$, and it is equal to 16.2 when the dependent variable is the $C_{-} C$. This robustness check seems very important; it indicates that the threshold value of the disproportionality index is not easily determined. The threshold value would allow to identify the direction of the indirect effect of the degree of proportionality on corruption, and therefore, to deal with the total effect. In our estimations, it depends on the corruption index we use, but, probably, it may widely vary among countries depending on their specific characteristics.

\section{Concluding remarks}

This work extends the $A B C$ paper to an international context. The very interesting results they found, within the Italian scenario, on the role played by political competition in the link between the electoral system and corruption required further investigations in order to be generalized. Therefore, we test the same hypothesis as in $A B C$ on a cross-country panel data, from 1984 to 2010. Our findings, firstly, contradicts previous empirical literature on cross-country data that makes plurality systems those most virtuous in terms of corruption. The interpretation of this reversed result can be due to the use of a more suitable measure of electoral rules, as a degree of proportionality index, instead of a dummy variable, that allowed us to properly consider all electoral systems in an empirical setting. Secondly, they confirm that one cannot draw conclusions about the way the electoral system could be designed as a tool in fighting corruption without considering political competition. Again we stress the fact that how political competition reacts to changes in the degree of proportionality of the electoral system, both theoretically and empirically, remains, until now, still unexplored.

\section{References}

Abdiweli, Ali M. and Isse S. Hodan (2003) 'Determinants of Economic Corruption: A Cross-Country Comparison', Cato Journal 22(3): 449-466.

Ades, Alberto and Rafael Di Tella (1999) 'Rents, Competition, and Corruption', American Economic Review 89(4): 982-92.

Aidt, Toke S. (2003) 'Economic Analysis of Corruption: A Survey', The Economic Journal, 113: 632-652.

Aidt, Toke S. (2011) 'The Causes of Corruption', CESifo DICE Report, Ifo Institute for Economic Research at the University of Munich 9(2): 15-19.

Alfano Maria R. and Anna L. Baraldi (2012) 'Is There an Optimal Level of Political Competition in Terms of Economic Growth? Evidence from Italy', European Journal of Law and Economics 39(2): 263-285.

Alfano, Maria R., Anna L Baraldi and Claudia Cantabene (2013) 'The Role of Political in the Link Between Electoral Systems and Corruption: the Italian Case', The Journal of Socio-Economics 47(1): 1-10.

Anckar, Carsten (2001) 'Effects of Electoral Systems. A study of 80 Countries', Working Paper presented at the SNS Seminar in Stockholm.

Arellano, Manuel and Stephen Bond (1991) 'Some Tests of Specification for Panel Data: Monte Carlo Evidence and an Application to Employment Equation', The Review of Economic Studies 58(2): 277-297.

Bardhan, Pranab and Tsung-Tao Yang (2004) 'Political Competition in Economic Perspective', Bureau for Research and Economic Analysis of Development, Working Paper 78. 
Besley, Timothy, Torsten Persson and Daniel M. Sturm (2010) 'Political Competition and Economic Performance: Theory and Evidence from the United States', Review of Economic Studies 77: 1329-1352.

Blundell, Richard and Stephen Bond (1998) 'GMM Estimation with Persistent Panel Data: An Application To Production Functions', Institute for Fiscal Studies, Working Paper Series, n. 99/4.

Bonaglia, Federico, Jorge Braga de Macedo and Maurizio Bussolo (2001) 'How Globalization Improves Governance', Discussion Paper n. 2992, Centre for Economic Policy Research, Organisation for Economic Co-operation and Development, Paris, France.

Brunetti, Aymo and Beatrice Weder (2003) 'A Free Press is Bad News for Corruption', Journal of Public Economics 87(7-8): 1801-1824.

Cox, Gary W. (1997) Making Votes Count: Strategic Coordination in the World's Electoral Systems. Cambridge: Cambridge University Press.

CPI. (2012) URL (consulted June 2015): http://www.transparency.org/cpi2012/in_detail

De Haan, Jakob and Harry Seldadyo (2005) 'The Determinants of Corruption: A Reinvestigation', unpublished paper prepared for the EPCS-2005 Conference Durham, England, 31 March-3 April 2005.

Dollar David, Raymon Fisman and Roberta Gatti (1999) 'Are Women Really the Fairer Sex? Corruption and Women in Government', World Bank Working Paper Series 4.

Duverger, Maurice (1954) Political parties: Their organization and activity in the modern state. London, Wiley. New York: Methuen.

Fisman, Raymon and Roberta Gatti (2002) 'Decentralization and Corruption: Evidence across Countries', Journal of Public Economics 83(3): 325-345.

Forejohn, John (1986) 'Incumbent performance and electoral control', Public Choice 50: 5-25.

Frechette, Guillaume R. (2001) 'A Panel Data Analysis of the Time-Varying Determinants of Corruption', Paper presented at the EPCS.

Gagliarducci, Stefano, Tommaso Nannicini and Paolo Naticchioni (2011) 'Electoral Rules and Politicians' Behavior: A Micro Test', American Economic Journal: Economic Policy 3(3): 144-174.

Gallagher, Michael (1991) 'Proportionality, Disproportionality and Electoral Systems', Electoral Studies 10(1): 33-51.

Gleditsch, Nils P. and Havard Hegre (1997) 'Peace and Democracy: Three Levels of Analysis', Journal of Conflict Resolution 41(2): 283-310.

Goetz, Anna M. (2004) Political Cleaners: How Women are the New Anti-Corruption Force. Does the Evidence Wash? URL (consulted May 2015): http://www.u4.no/document/showdoc. cfm?id=124.

Hall, Robert E. and Charles I. Jones (1999) 'Why do Some Countries Produce so much more Output per Worker than Others', Quarterly Journal of Economics 114: 83-116.

Kaufmann, Daniel, Aart Kraay and Massimo Mastruzzi (1999) 'Governance Matters', World Bank Policy Research Working Paper 2196.

Knack, Stephen and Omar Azfar (2003) 'Trade Intensity, Country Size and Corruption', Economics of Governance 4: 1-18. 
Kunicova, Jana and Susan Rose-Ackerman (2005). 'Electoral Rules and Constitutional Structures as Constraints on Corruption', British Journal of Political Science 35(4): 573-606.

La Porta, Rafael, Florencio Lopez-de-Silanes, Andrei Shleifer and Robert W. Vishny(1999) 'The Quality of Government', Journal of Law, Economics, and Organization' 15(1): 222-79.

Lijphart, Arend (1994) Electoral System and Party Systems: A Study of Ttwentyseven Democracies, 1945-1990. New York: Oxford University Press.

Maddala, Gangadharrao S. and Shaowen Wu (1999) 'A Comparative Study of Unit Root Tests with Panel Data and New Simple Test', Oxford Bullertin of Economics and Statistics, pp. 631-652.

Mulligan, Casey B., Tsui, Kevin T. (2006). 'Political Competitiveness', NBER Working Paper 12653.

Myerson, Roger B. (1993) 'Effectiveness of Electoral Systems for Reducing Government Corruption: A Game-theoretic Approach', Games and Economic Behavior 5(1): 118-32.

Padovano, Fabio and Roberto Ricciuti (2009) 'Political Competition and Economic Performance: Evidence from the Italian Regions', Public Choice 138(3-4): 263-277.

Persson, Torsten and Guido E. Tabellini (1999a) 'The Size and Scope of Government: Comparative Politics with Rational Politicians', European Economic Review 43(4-6): 699-735.

Persson, Torsten and Guido E. Tabellini (1999b) 'Political Economics and Public Finance', in Auerbach, Alan J., Feldstein, Martin. (eds.) Handbook of Public Economics. Vol. 3. Amsterdam: NorthHolland.

Persson Torsten and Guido E. Tabellini (2000) Political Economics: Explaining Economic Policy. Cambridge: The MIT Press.

Persson, Torsten, Guido E. Tabellini and Francesco Trebbi (2003) 'Electoral Rules and Corruption', Journal of the European Economic Association 1(4):958-989.

Persson, Torsten, Gerard Roland and Guido E. Tabellini (1997) 'Separation of Powers and Political Accountability', Quarterly Journal of Economics 112(4): 11631202.

Powell, G. Bingham and Georg S. Vanberg (2000) 'Election Laws, Dis-proportionality and Median Correspondence: Implications for Two Visions of Democracy', British Journal of Political Science 30(3): 383-411.

Roodman, David. (2009) 'How To Do Xtabond2: An Introduction To Difference and System GMM in Stata', Stata Journal 9: 86-136.

Rose-Ackerman, Susan (1999) Corruption and Government, Causes, Consequences and Reform. Cambridge: Cambridge University Press.

Sartori, Giovanni (1976) Parties and Party Systems: A Framework for Analysis. Cambridge: Cambridge University Press.

Snyder, James M., Stromberg, David (2008) 'Press Coverage and Political Accountability', Journal of Political Economy 118(2): 355-408.

Stigler, George J. (1972) 'Economic Competition and Political Competition', Public Choice 13(1): 91-106.

Sung, Hyung Jin (2003) 'Fairer Sex or Fairer System? Gender and Corruption Revisited', Social Forces 82(2): 703-723.

Taagepera, Rein and Matthew Shugart (1989) Seats and Votes: The Effects and Determinants of Electoral Systems. New Haven: Yale University Press. 
Tanzi, Vito (1998) 'Corruption around the World: Causes, Consequences, Scope and Cures', IMF Staff Papers 45(4): 559-94.

Tavares, Jóse (2003) 'Does Foreign Aid Corrupt?', Economic Letters 79: 99-106.

Treisman, Daniel (2000) 'The Causes of Corruption: A Cross-national Study', Journal of Public Economics 76(3): 399-57.

Windmeijer, Frank (2005) 'A Finite Sample Correction for the Variance of Linear Efficient Two-step GMM Estimators', Journal of Econometrics 126(1): 25-51. 


\section{Appendix}

\section{Table A1: Variables description}

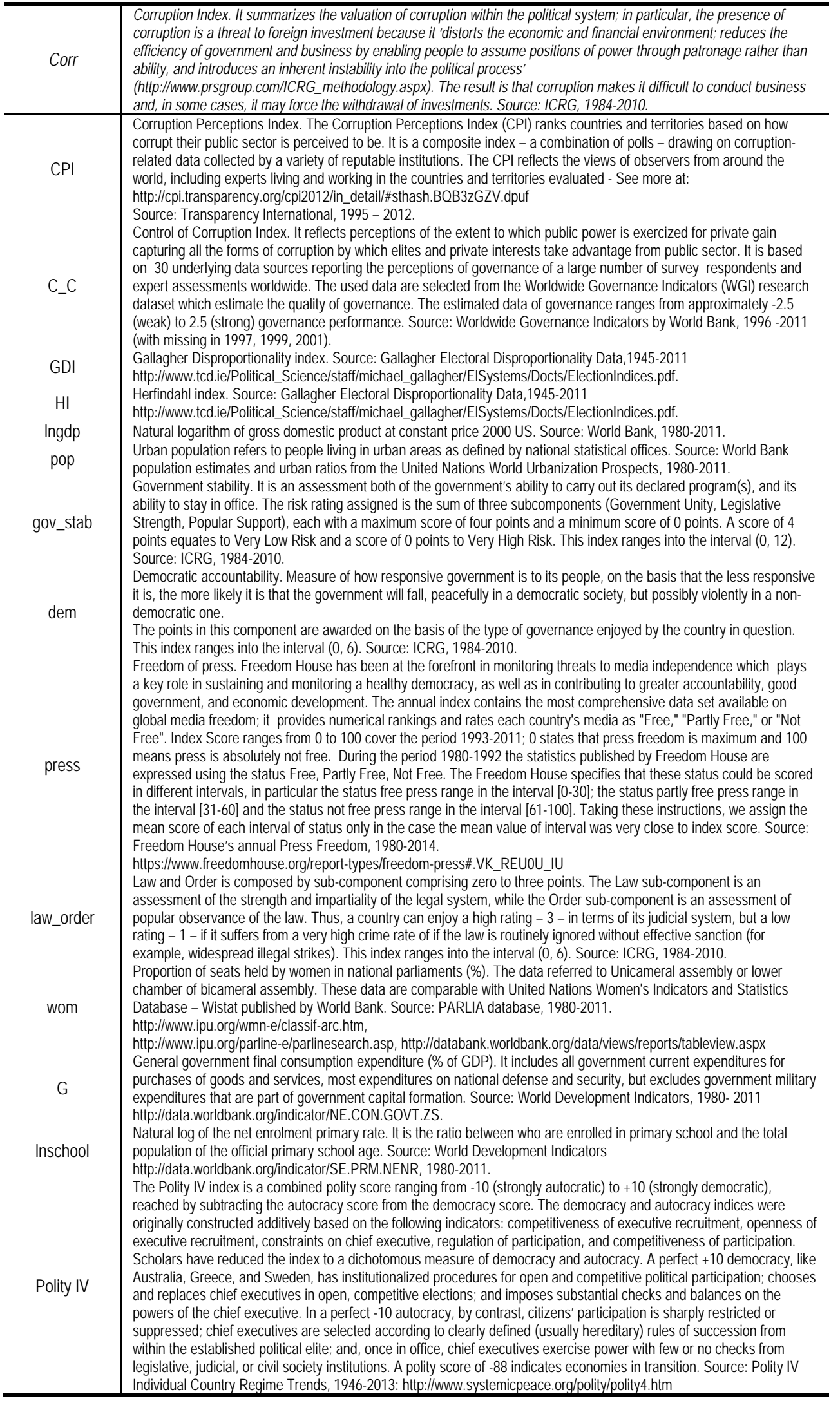


Table A2: Descriptive statistics of variables

\begin{tabular}{|c|c|c|c|c|c|c|}
\hline Variable & Mean & & Std. Dev. & Min & Max & Observations \\
\hline \multirow[t]{2}{*}{ Corr } & \multirow[t]{3}{*}{3.39} & overall & 1.41 & 0 & 6 & $N=2160$ \\
\hline & & between & 1.18 & & & $n=85$ \\
\hline \multirow{4}{*}{$\mathrm{CPI}$} & & within & 0.76 & & & $\mathrm{~T}=25$ \\
\hline & \multirow[t]{2}{*}{5.02} & overall & 2.4 & 0.4 & 10 & $N=1223$ \\
\hline & & between & 2.32 & & & $\mathrm{n}=85$ \\
\hline & \multirow{3}{*}{0.34} & overall & $\begin{array}{l}0.5 \\
1.08\end{array}$ & 17 & & $\mathrm{~T}=14$ \\
\hline \multirow{2}{*}{ C_C } & & between & $\begin{array}{l}1.08 \\
1.07\end{array}$ & -1.7 & 2.56 & $N=1105$ \\
\hline & & within & $\begin{array}{l}1.07 \\
0.18\end{array}$ & & & $\mathrm{n}=85$ \\
\hline \multirow{3}{*}{ GDI } & \multirow{3}{*}{7.64} & overall & 6.54 & 0.26 & 33.25 & $N=1975$ \\
\hline & & between & 5.46 & & & $\mathrm{n}=85$ \\
\hline & & within & 3.67 & & & $\mathrm{~T}=23$ \\
\hline \multirow[t]{3}{*}{$\mathrm{HI}$} & \multirow[t]{3}{*}{0.3} & overall & 0.13 & 0.06 & 0.89 & $N=1772$ \\
\hline & & between & 0.12 & & & $\mathrm{n}=79$ \\
\hline & & within & 0.06 & & & $\mathrm{~T}=22$ \\
\hline \multirow[t]{3}{*}{ Ingdp } & \multirow[t]{3}{*}{8.25} & overall & 1.46 & 4.9 & 10.9 & $N=2566$ \\
\hline & & between & 1.44 & & & $n=83$ \\
\hline & & within & 0.22 & & & $\mathrm{~T}=31$ \\
\hline \multirow[t]{3}{*}{ рор } & \multirow[t]{3}{*}{$3.97 e+07$} & overall & $1.14 \mathrm{e}+08$ & 210600 & $1.24 \mathrm{e}+09$ & $N=2688$ \\
\hline & & between & $1.13 e+08$ & & & $n=84$ \\
\hline & & within & $1.89 e+07$ & & & $\mathrm{~T}=32$ \\
\hline \multirow[t]{3}{*}{ gov_stab } & \multirow[t]{3}{*}{7.63} & overall & 2.01 & 1 & 11.5 & $N=2153$ \\
\hline & & between & 0.88 & & & $n=85$ \\
\hline & & within & 1.82 & & & $\mathrm{~T}=25$ \\
\hline \multirow[t]{3}{*}{ dem } & \multirow[t]{3}{*}{4.92} & overall & 1.79 & 0 & 11.5 & $N=2153$ \\
\hline & & between & 1.43 & & & $n=85$ \\
\hline & & within & 1.05 & & & $\mathrm{~T}=25$ \\
\hline \multirow[t]{3}{*}{ press } & \multirow[t]{3}{*}{33.4} & overall & 19.2 & 5 & 100 & $N=1762$ \\
\hline & & between & 18.2 & & & $\mathrm{n}=85$ \\
\hline & & within & 6.2 & & & $\mathrm{~T}=21$ \\
\hline \multirow[t]{3}{*}{ law_order } & \multirow[t]{3}{*}{3.93} & overall & 1.53 & 0 & 6 & $N=2153$ \\
\hline & & between & 1.32 & & & $n=85$ \\
\hline & & within & 0.75 & & & $\mathrm{~T}=25$ \\
\hline wom & 14.4 & overall & 10.1 & 0 & 47.3 & $N=2347$ \\
\hline & & between & 7.5 & & & $n=84$ \\
\hline & & within & 6.8 & & & $\mathrm{~T}=28$ \\
\hline G/GDP & 16.5 & overall & 5.98 & 2.9 & 43.4 & $N=2526$ \\
\hline & & between & 5.16 & & & $n=83$ \\
\hline & & within & 3.04 & & & $\mathrm{~T}=30$ \\
\hline G/POP & 0.08 & overall & 0.32 & $3.33 e-06$ & 2.99 & $N=2510$ \\
\hline & & between & 0.31 & & & $n=83$ \\
\hline & & within & 0.06 & & & $\mathrm{~T}=30$ \\
\hline Inschool & 4.48 & overall & 0.2 & 2.9 & 4.6 & $N=1494$ \\
\hline & & between & 0.17 & & & $n=81$ \\
\hline & & within & 0.08 & & & $\mathrm{~T}=18$ \\
\hline Polity IV & 8.4 & overall & 1.79 & 4 & 10 & $\mathrm{~N}=1995$ \\
\hline & & between & 1.73 & & & $\mathrm{n}=79$ \\
\hline & & within & 0.73 & & & $\mathrm{~T}=25$ \\
\hline
\end{tabular}


Table A3. Correlations

\begin{tabular}{|c|c|c|c|c|c|c|c|c|c|c|c|c|c|}
\hline & $\begin{array}{c}\text { cor } \\
r\end{array}$ & $\begin{array}{c}G D \\
l\end{array}$ & $H I$ & $\begin{array}{c}\text { Ingd } \\
p\end{array}$ & $\begin{array}{l}\text { po } \\
p\end{array}$ & $\begin{array}{c}\text { gov_st } \\
a b\end{array}$ & $\begin{array}{l}d e \\
m\end{array}$ & $\begin{array}{c}\text { pres } \\
\mathrm{s}\end{array}$ & $\begin{array}{c}\text { law_ord } \\
\text { er }\end{array}$ & $\begin{array}{c}\text { wo } \\
m\end{array}$ & $\begin{array}{c}G / G D \\
P\end{array}$ & $\begin{array}{c}G / P O \\
P\end{array}$ & $\begin{array}{c}\text { Inscho } \\
\text { ol }\end{array}$ \\
\hline corr & 1 & & & & & & & & & & & & \\
\hline GDI & $\overline{0} \overline{2}$ & 1 & & & & & & & & & & & \\
\hline $\mathrm{HI}$ & $\begin{array}{c}- \\
0.2 \\
4\end{array}$ & $\begin{array}{c}0.1 \\
7\end{array}$ & 1 & & & & & & & & & & \\
\hline Ingdp & $\begin{array}{c}0.6 \\
3\end{array}$ & $\begin{array}{c}- \\
0.2 \\
3\end{array}$ & $\begin{array}{c}- \\
0.3 \\
4\end{array}$ & 1 & & & & & & & & & \\
\hline pop & $\begin{array}{c}- \\
0.0 \\
9\end{array}$ & $\begin{array}{c}- \\
0.0 \\
2\end{array}$ & $\begin{array}{c}- \\
0.0 \\
8\end{array}$ & 0.05 & 1 & & & & & & & & \\
\hline gov_sta $_{\mathrm{b}}$ & $\begin{array}{c}0.0 \\
8\end{array}$ & $\begin{array}{c}0.0 \\
8\end{array}$ & $\begin{array}{c}0.1 \\
1\end{array}$ & 0.11 & $\begin{array}{c}- \\
0.0 \\
4\end{array}$ & 1 & & & & & & & \\
\hline dem & $\begin{array}{c}0.3 \\
5\end{array}$ & $\begin{array}{c}- \\
0.2 \\
8\end{array}$ & $\begin{array}{c}- \\
0.2 \\
6\end{array}$ & 0.38 & $\begin{array}{c}0.0 \\
2\end{array}$ & 0.08 & 1 & & & & & & \\
\hline press & 0.6 & $\begin{array}{c}0.1 \\
9\end{array}$ & $\begin{array}{c}0.1 \\
5\end{array}$ & -0.8 & $\begin{array}{c}0.0 \\
9\end{array}$ & -0.12 & $\overline{-}$ & 1 & & & & & \\
\hline $\begin{array}{c}\text { law_ord } \\
\overline{\text { er }}\end{array}$ & 0.7 & $\begin{array}{c}- \\
0.1 \\
8\end{array}$ & $\begin{array}{c}- \\
0.2 \\
8\end{array}$ & 0.66 & $\begin{array}{c}- \\
0.0 \\
6\end{array}$ & 0.12 & $\begin{array}{c}0.3 \\
9\end{array}$ & -0.6 & 1 & & & & \\
\hline wom & $\begin{array}{c}0.3 \\
9\end{array}$ & $\begin{array}{c}- \\
0.3 \\
8\end{array}$ & $\begin{array}{c}- \\
0.1 \\
6\end{array}$ & 0.33 & $\begin{array}{c}- \\
0.1 \\
3\end{array}$ & 0.06 & $\begin{array}{c}0.2 \\
1\end{array}$ & -0.5 & 0.28 & 1 & & & \\
\hline G/GDP & $\begin{array}{c}0.4 \\
3\end{array}$ & $\begin{array}{c}- \\
0.1 \\
8\end{array}$ & $\begin{array}{c}- \\
0.1 \\
8\end{array}$ & 0.45 & $\begin{array}{c}- \\
0.1 \\
6\end{array}$ & -0.01 & $\begin{array}{c}0.1 \\
4\end{array}$ & 0.44 & 0.51 & $\begin{array}{c}0.3 \\
7\end{array}$ & 1 & & \\
\hline G/POP & $\begin{array}{c}0.2 \\
7\end{array}$ & $\begin{array}{c}- \\
0.1 \\
4\end{array}$ & $\begin{array}{c}- \\
0.0 \\
1\end{array}$ & 0.28 & - & 0.17 & $\begin{array}{c}0.0 \\
4\end{array}$ & 0.26 & 0.25 & $\begin{array}{c}0.1 \\
4\end{array}$ & 0.14 & 1 & \\
\hline Inschool & $\begin{array}{c}0.2 \\
2\end{array}$ & $\begin{array}{c}- \\
0.1 \\
8\end{array}$ & $\overline{0}$ & 0.6 & $\begin{array}{c}0.0 \\
4\end{array}$ & -0.01 & $\begin{array}{c}0.3 \\
7\end{array}$ & 0.38 & 0.33 & $\begin{array}{c}0.1 \\
5\end{array}$ & 0.32 & 0.1 & 1 \\
\hline
\end{tabular}

Table A4: C test. Dependent variable: Corruption Index

\begin{tabular}{c|cc}
\hline & $(a)$ & $\left(\mathbf{a}^{\prime}\right)$ \\
\hline corr (-1) & $1.83^{\star \star \star}$ & $(20.8)$ \\
corr (-2) & $(20.8)$ & $-0.23^{\star \star \star *}$ \\
GDI & $-0.23^{\star \star \star}$ & $(-5.7)$ \\
& $(-5.7)$ & -0.007 \\
HI & $-0.01^{\star \star}$ & $(-0.17)$ \\
& $(-2.23)$ & -0.42 \\
GDI *HI & $-0.48^{\star *}$ & $(-0.7)$ \\
& $(-1.92)$ & 0.13 \\
Ingdp & $0.02^{\star * \star}$ & $(0.17)$ \\
pop & $(2.6)$ & 0.02 \\
N. obs. (n. groups) & 0.02 & $(0.4)$ \\
N. instrum. & $(0.7)$ & $-6.23 e-11$ \\
Chi2Hansen test & $-5.77 e-11$ & $(-0.5)$ \\
(dof) & $(-0.5)$ & $1303(70)$ \\
p-value 2nd order autocorrelation & $1303(70)$ & 35 \\
\hline
\end{tabular}

Notes. All specifications contain calendar year dummies (results not reported); the time span is 1984-

2010. The dependent variable is Corr. Standardized normal z-test values are in parentheses; cluster-

robust standard errors. Ingdp is treated as endogenous everywhere. In (a) GDI is treated as exogenous

while in (a') it is treated as endogenous and it is instrumented with its own lags. Significant coefficients

are indicated by * (10\% level), ** (5\% level) and *** (1\% level). Two-step estimations with Windmeijer

(2005) correction. 